University of South Florida

DIGITAL COMMONS

Digital Commons @ University of

@ UNIVERSITY OF SOUTH FLORIDA

South Florida

KIP Monographs

KIP Research Publications

January 2012

\title{
The El Gigante Rockshelter: Preliminary Observations on an Early to Late Holocene Occupation in Southern Honduras.
}

Timothy E. Scheffler

Kenneth G. Hirth

George Hasemann

Follow this and additional works at: https://digitalcommons.usf.edu/kip_monographs

\section{Recommended Citation}

Scheffler, Timothy E.; Hirth, Kenneth G.; and Hasemann, George, "The El Gigante Rockshelter: Preliminary Observations on an Early to Late Holocene Occupation in Southern Honduras." (2012). KIP Monographs. 8.

https://digitalcommons.usf.edu/kip_monographs/8

This Book is brought to you for free and open access by the KIP Research Publications at Digital Commons @ University of South Florida. It has been accepted for inclusion in KIP Monographs by an authorized administrator of Digital Commons @ University of South Florida. For more information, please contact digitalcommons@usf.edu. 


\title{
THE EL GIGANTE ROCKSHELTER: PRELIMINARY OBSERVATIONS ON AN EARLY TO LATE HOLOCENE OCCUPATION IN SOUTHERN HONDURAS
}

\author{
Timothy E. Scheffler, Kenneth G. Hirth, and George Hasemann
}

\begin{abstract}
The El Gigante rockshelter in highland Honduras was occupied as early as 10,000 years B.P. and provides information previously lacking about the earliest periods of Honduran and Central American prehistory. Three distinct cultural horizons were identified and dated at the site using conventional and accelerator mass spectrometry radiocarbon dates that correspond to the Early Archaic, the Middle Archaic, and the Formative to Classic periods. Dry conditions within the rockshelter resulted in excellent archaeological preservation across all time periods. Excavations documented a clear sequence of residential activity represented by well-defined cultural strata containing hearth and pit features as well as dense deposits of lithic, macrobotanical, and faunal remains. The variety of food items found throughout the transition from foraging to food production suggests the long-term maintenance of diet breadth in the context of a mixed and flexible subsistence economy. The El Gigante site reveals key information regarding the early occupation of Central America, the flora and fauna resources used by middle Holocene foragers, and the domesticated plant species cultivated during the late Holocene occupation of the rockshelter.
\end{abstract}

La cueva de El Gigante en las tierras altas de Honduras fue ocupada tan temprano como 10,000 años a.P. y da información previamente desconocida sobre la prehistoria de Honduras. Las condiciones climáticas secas resultan en una excelente preservación de esta área residencial. Las excavaciones documentaron una clara secuencia de ocho estratos culturales bien definidos que contienen hogares, así como depósitos densos de lítica, y restos microbotánicos y faunísticos. Basándose en métodos de fechamiento de radiocarbon convencional y AMS, se identificaron tres horizontes culturales distintos. La ocupación más antigua es de la fase Esperanza, la cual representa ocupación del Arcaico Temprano que se extiende entre 10,040-9100 a.P. La segunda es la fase Marcala que corresponde al periodo Arcaico Medio, entre 7350-6050 a.P. La tercera y más reciente ocupación en estas cuevas es en la fase Estanzuela, entre 3900-1500 a.P. El Gigante fue usado como residencia durante los dos periodos del Arcaico. Varias puntas de proyectil largas fueron recuperadas en niveles estratigráficos claramente identificados como del Paleoindio. El examen de los datos faunísticos muestra que, mientras disminuyen los huesos de mamíferos grandes, aumentan los de mamíferos de menor tamaño y los de animales no mamíferos. Una gran cantidad de maíz (Zea sp.) está presente en el sitio durante el periodo Estanzuela. La variedad de materiales de comida encontrados entre la transición sugiere el mantenimiento a largo plazo de una amplitud dietética en el contexto de una economía flexible y mezclada. El Gigante es un sitio que revela información clave en relación a la colonización inicial de Centroamérica y la incorporación de especies domesticadas dentro de una base de forrajeo que acompaña a la transición a la agricultura.

I

$n$ recent years a great deal of new information has been collected on the late Pleistocene and early to middle Holocene adaptations in Mexico and Central America. Much of this information has come from paleoenvironmental and isotopic analyses of material evidence from nonresidential contexts (e.g., Jones 1994; Pohl et al. 1996). Information from in situ residential sites, however, remains limited. Good information on Holocene

occupations exists for areas of Belize (Hester et al . 1996; Iceland 1997; Lohse 2007; Lohse et al. 2006; MacNeish and Nelken-Terner 1983), the southeastern coast of Mexico (Voorhies 1976, 2004; Voorhies et al. 2002), Guatemala (Brown 1980; Coe 1960), and central Panama (Cooke 2005; Ranere 2006; Ranere and Cooke 1996). In contrast, information is very limited on early human occupation in Honduras, El Salvador, Nicaragua, and

Timothy E. Scheffler Department of Anthropology, University of Hawai'i, Hilo, HI 96720 (scheffle@hawaii.edu) Kenneth G. Hirth $\mathbf{m}$ Department of Anthropology, 409 Carpenter Building, Pennsylvania State University, University Park,PA 16802 (kgh2@psu.edu) George Hasemann $\mathbf{m}$ Instituto Hondureño de Antropología e Historia, Tegucigalpa, Honduras (deceased)

Latin American Antiquity 23(4), 2012, pp. 597-610 Copyright (C2012 by the Society for American Archaeology 
Costa Rica (Clark and Cheetham 2002; but see Snarskis 1979). This vacuum needs to be filled if we are to develop a comprehensive understanding of human adaptation during the early and middle Holocene periods throughout middle America.

Late Paleoindian occupations have been reported from several sites in Central America. The evidence for late Paleoindian occupations consists largely of fluted bifaces recovered in stratigraphic contexts at sites such as Los Tapiales in highland Guatemala (Gruhn et al. 1977) and Cueva de Los Vampiros on the southern coast of Panama (Pearson 2002; Pearson and Cooke 2003). Investigations have also documented manufacturing locales of fluted points at quarry sites at both Turrialba, Costa Rica (Snarskis 1979), and the sites of Nieto (Pearson 2003) and La Mula West (Ranere 2006) on the Pacific coast of Panama. It is clear that Paleoindian foragers carrying Clovis technology extended throughout Central American and reached as far south as Panama during the late Pleistocene.

Less well known are sites where the Late Paleoindian-to-Early Archaic transition can be identified and followed into the early Holocene. Recent excavations at the El Gigante rockshelter in the Marcala region of southern Honduras (Scheffler 2008) have identified the presence of Early Archaic foragers who represent the early stages of this transition. The Early Archaic foragers at El Gigante occupied the rockshelter periodically throughout the year where they hunted, collected tree fruits, and exploited maguey and other resources. Their hunting technology included both fluted and unfluted projectile points that they used to exploit deer and a range of other large and small mammals. Research at El Gigante documents the adaptation of Early and Middle Archaic foragers to a mid-elevation highland valley of southern Honduras.

Of particular interest to researchers is the development and spread of maize agriculture from southern Mexico into adjacent areas of Guatemala and Central America. The earliest dated macroremains of maize from southern Mexico are from the Tehuacán Valley in Puebla and Guilá Naquitz in the Valley of Oaxaca, where cob fragments have been dated to between 5400 and 4700 B.P. (Piperno and Flannery 2001:2101). Phytolith and starch grains recovered from stone tools and stratigraphic levels at the Xihuatoxtla rockshelter document the earlier presence of maize in the central Balsas River drainage by 8700 B.P. (Piperno et al. 2009; Ranere et al. 2009). Maize spread south into Central America, reaching Panama perhaps as early as 7600 B.P. (Piperno and Pearsall 1998; Ranere et al. 2009:5014). Pollen cores from western Honduras suggest that maize was cultivated by slash-and-burn agriculturalists in this region by $5000-4500$ B.P. (Rue 1989; Webster et al. 2005). The excavations at El Gigante have recovered a sample of more than 9,000 maize cobs, cob fragments, husks, and stalk segments from late Holocene deposits, indicating that maize agriculture was a central component of the subsistence system by 2300-2200 B.P.

Explorations at El Gigante reveal a discontinuous occupation spanning nearly 9,000 years during the early to late Holocene periods. This report provides a broad outline of the major occupation episodes at El Gigante and demonstrates what the ongoing analysis of excavation remains can reveal about the human occupation and adaptation in the region beginning as early as 10,000 B.P.El Gigante straddles the transition from Paleoindian forgers to the appearance of sedentary agricultural populations and can significantly broaden our understanding of cultural adaptations in central Honduras during the early to late Holocene.

\section{El Gigante Rockshelter}

El Gigante is located at $1,300 \mathrm{~m}$ asl along the west side of the Estanzuela River north of the town of Marcala, La Paz (Figure 1). The area is dominated by pine-oak (Pinus-Quercus) forest, which transitions to a sweet gum forest (Liquidambar styraciflua) above $1,500 \mathrm{~m}$. The Estanzuela River is an upper tributary of the Lempa River and forms part of the greater Pacific watershed. Bedrock throughout the region is an ignimbrite tuff composed of welded ash, pumice, and pyroclastic debris. This tuff is part of the Padre Miguel Formation, which originated in the Miocene and Pliocene epochs from 23 to 1.5 million years ago. El Gigante was formed by a relic channel of the Estanzuela River that undercut the ignimbrite tuff to carve out the rockshelter. Observations indicate that there was little to no erosion of the rockshelter during the Holocene. As a result cultural materials deposited here over the last 10,000 years have been well preserved.

Downcutting by the Estanzuela River has isolated the rockshelter on an elevated shelf within the 


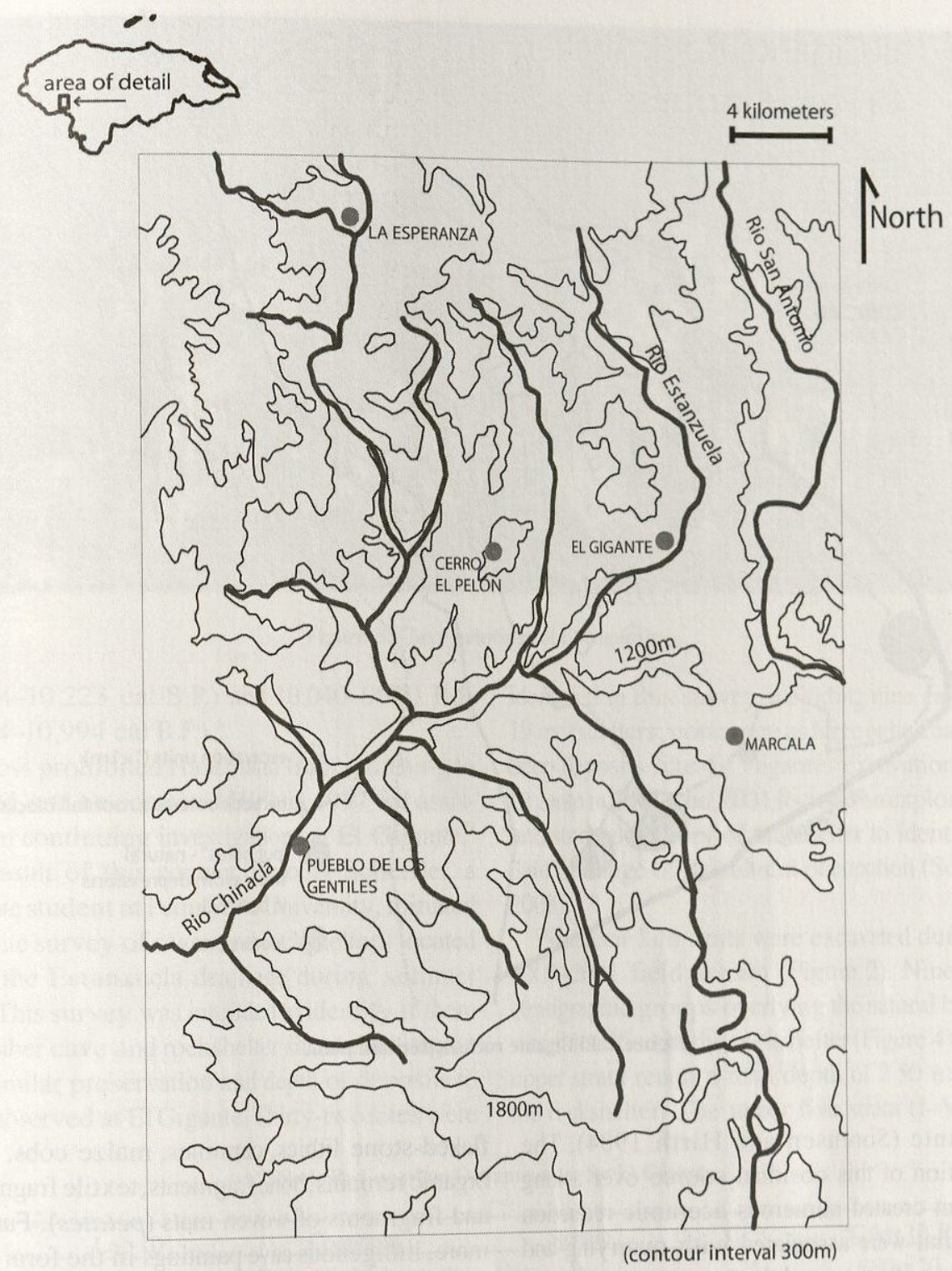

Figure 1. Location of El Gigante in highland Honduras.

face of a 6-m vertical scarp. The rockshelter measures $42 \mathrm{~m}$ across its mouth, $17 \mathrm{~m}$ deep, and more than $12 \mathrm{~m}$ high (Figure 2). The site's location in the vertical cliff face has made access difficult throughout the length of human occupation, and a ladder is required to enter it today. The cave has approximately $357 \mathrm{~m}^{2}$ of horizontal floor area, which slopes from north to south, with the north end 3-5 $\mathrm{m}$ higher than the south. On the basis of physical evidence collected during stratigraphic excavations, we believe that the rockshelter existed much as it does today throughout the period of human occupation.

The possibility of early occupation in the region was first suggested by Bullen and Plowden (1963) and later reiterated by MacNeish (1986; MacNeish and Nelken-Terner 1983). Bullen and Plowden originally argued for a Paleoindian occupation based on the presence of aceramic sites with bifacial projectile points made of obsidian. This possibility was questioned because the La Esperanza obsidian source is located just $22 \mathrm{~km}$ northwest of 


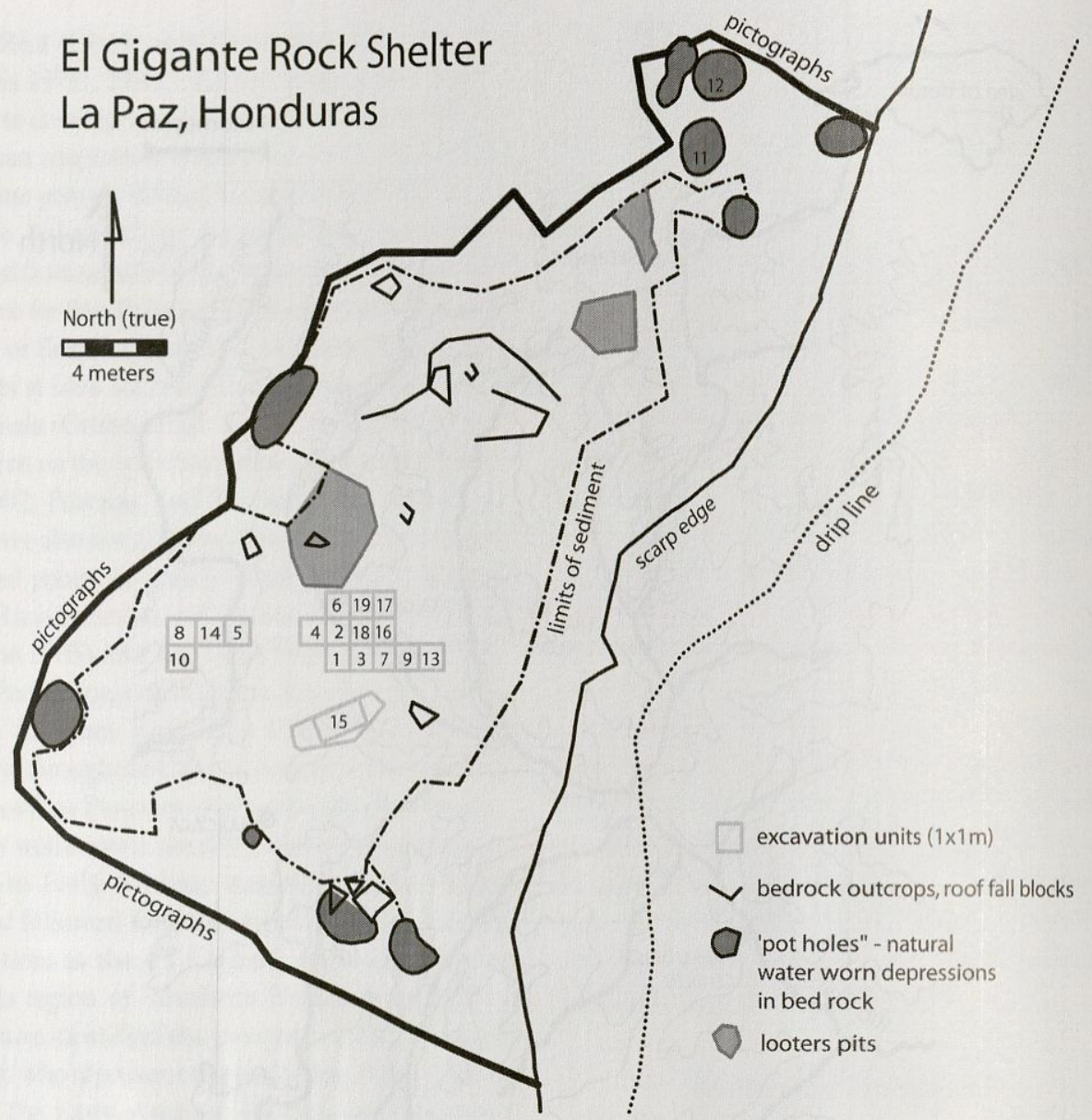

Figure 2. El Gigante rockshelter site plan.

El Gigante (Sorensen and Hirth 1984). The exploitation of this obsidian source over a long time span created numerous aceramic reduction locales that were associated with quarrying and preforming obsidian nodules.

Reports of looting brought El Gigante to the attention of the Instituto Hondureño de Antropología e Historia in the early 1990s. The site was visited by George Hasemann, head of the archaeology division of the institute, who immediately recognized the rockshelter's research potential from the quantity of artifacts scattered across the shelter's floor. The rockshelter's location in the side of the escarpment protected its interior from rainfall and surface runoff, resulting in a dry depositional environment. Excellent conditions of preservation were evident from the range of materials observed within the shelter, which included flaked-stone lithics, ceramics, maize cobs, other organic remains, bone fragments, textile fragments, and fragments of woven mats (petates). Furthermore, indigenous cave paintings in the form of 13 dark handprints were located on its interior walls (Figure 3). No vegetation grows inside the rockshelter, and the majority of its interior is $8 \mathrm{~m}$ or more inside the normal drip line (Figure 2).

Initial explorations at El Gigante were initiated by Hasemann in 1993 and 1994. In 1993 surface collections were made and one of the looter's pits was straightened to draw the profile and collect samples of datable material. Expansion of the 1993 test excavation revealed over $2 \mathrm{~m}$ of stratified deposits as well as a possible early "fishtail" projectile point (see below) and two radiocarbon samples (Table 1, samples 16 and 17) from early occupation levels that dated to $9520-9380$ B.P. 


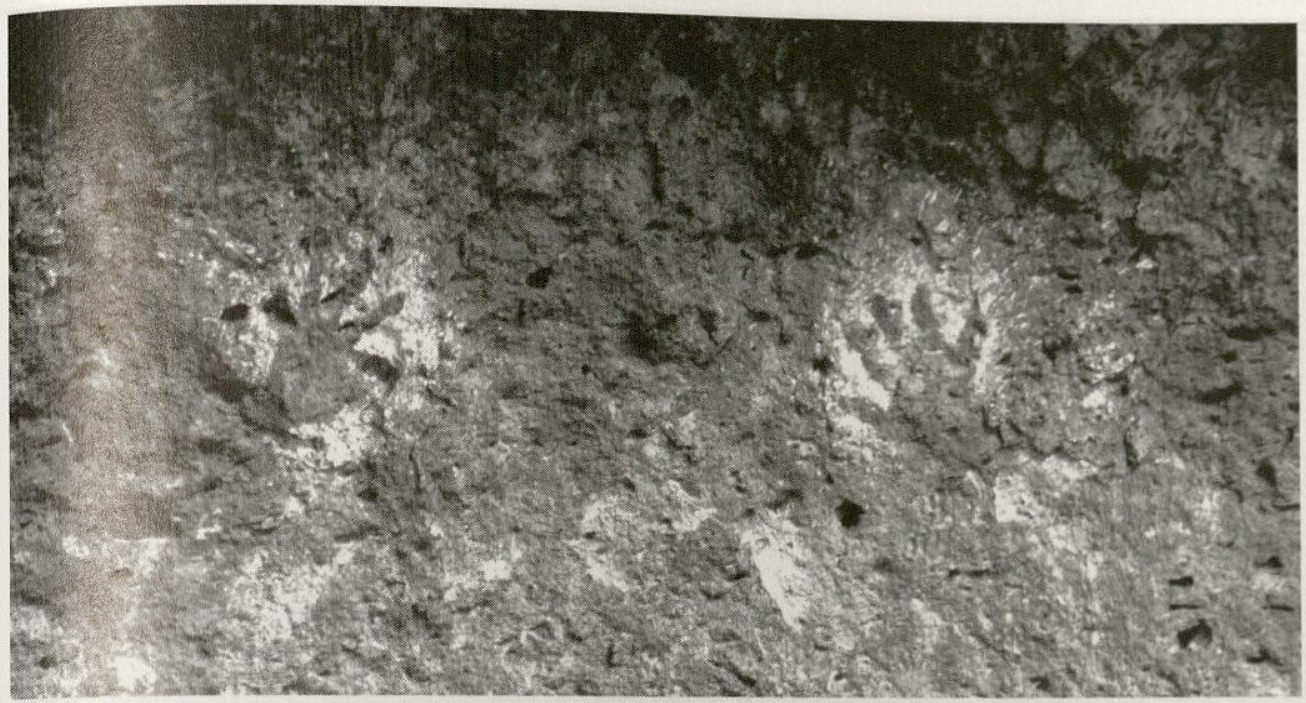

Figure 3. Cave paintings at El Gigante.

(10,884-10,223 cal B.P.) and 10,040-9900 B.P. (11,854-10,994 cal B.P.). ${ }^{1}$

Illness prohibited Hasemann from returning to the field, and he contacted Hirth in 1997 for assistance in continuing investigations at El Gigante. ${ }^{2}$ As a result of this contact Timothy Scheffler, a graduate student at Penn State University, initiated a key site survey of caves and rockshelters located along the Estanzuela drainage during summer 1998. This survey was intended to identify if there were other cave and rockshelter sites in the region with similar preservation and depth of deposits to those observed at El Gigante. Thirty-two sites were identified in this survey, including nine caves and 19 rockshelters; none were as large or had early and deep deposits like El Gigante. Excavations at El Gigante in 2000 and 2001 focused on exploring the undisturbed sectors of the shelter to identify and date the range of its cultural occupation (Scheffler 2008).

Nineteen 1-m units were excavated during the 2000-2001 field season (Figure 2). Nine major stratigraphic groups overlying the natural bedrock were identified in the rockshelter (Figure 4). These upper strata reach a total depth of $2.50 \mathrm{~m}$ within the rockshelter. The upper five strata $(\mathrm{I}-\mathrm{V})$ were

Table 1. Radiocarbon Determinations for El Gigante.

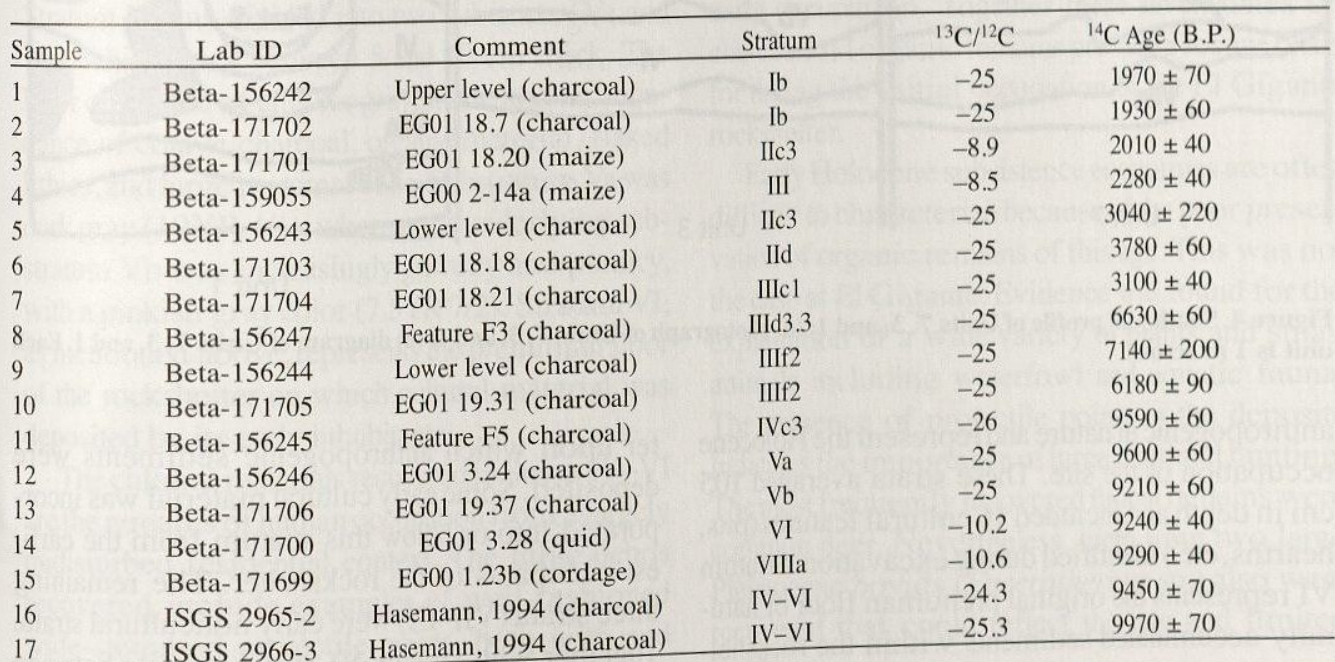



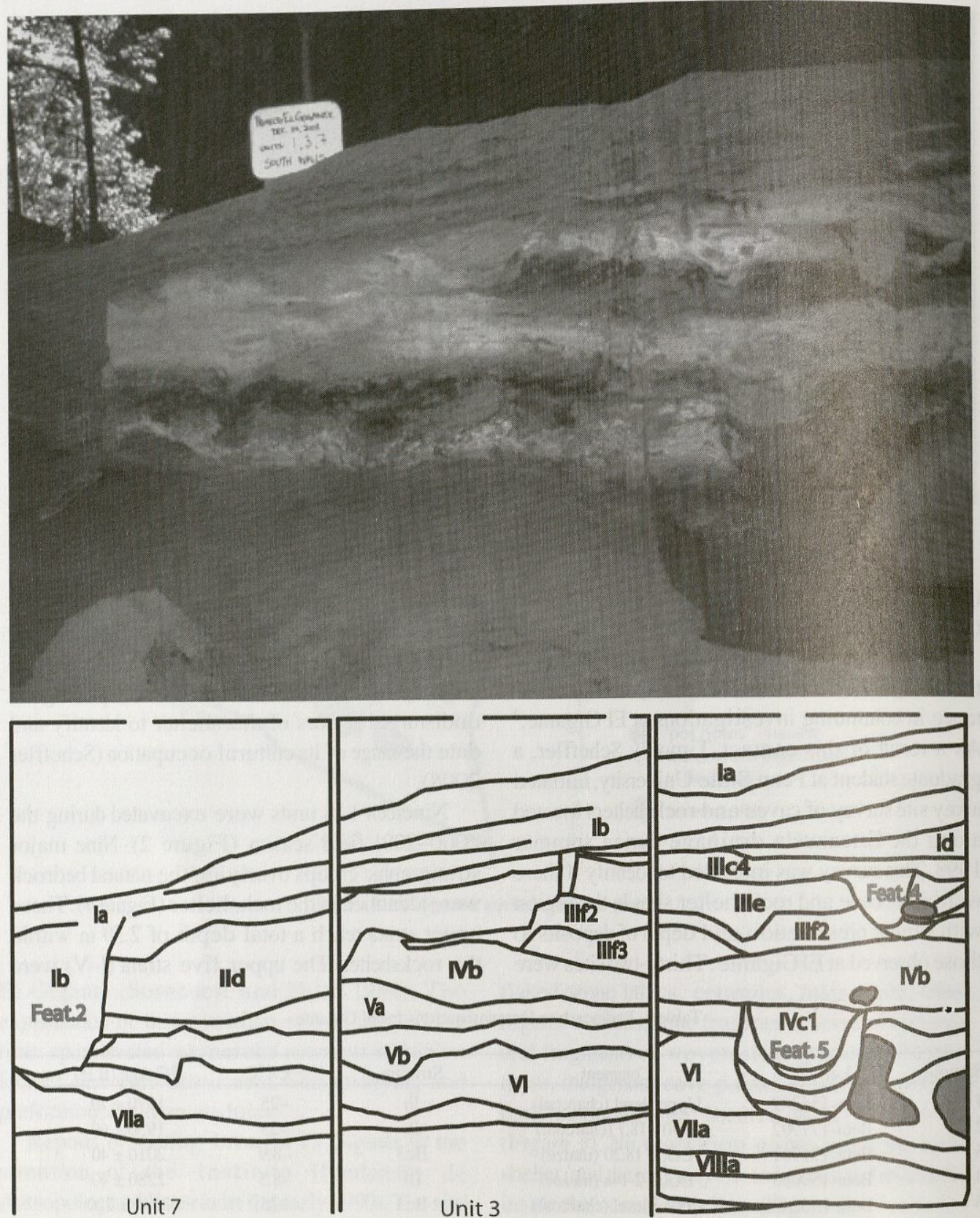

Unit 1

Figure 4. South wall profile of Units 7,3, and 1: (a) photograph of Units 7,3, and 1; (b) diagram of Units 7,3, and 1. Each unit is $1 \mathrm{~m}$ across.

anthropogenic in nature and represent the Holocene occupation of the site. These strata averaged 105 $\mathrm{cm}$ in depth and included 16 cultural features (pits, hearths, etc.) identified during excavation. Stratum VI represents the original prehuman floor of naturally accumulated sediments within the rockshel- ter upon which anthropogenic sediments were deposited. Some early cultural material was incorporated into or below this stratum from the earliest occupants of the rockshelter. The remaining three strata (VII-IX) were early noncultural strata. Together with Stratum VI, they alternate between 
white, indurated, and pumicy tephras (Strata VI and VIII) of volcanic origin and the very carbonaceous, loose, black soils (Strata VII and IX) sandwiched between them (Scheffler 2008:62).

Three major cultural occupations were identified during the 2000-2001 field season, which were dated with 15 radiocarbon dates (Table 1). These dates together with the two radiocarbon dates processed by Hasemann bring the number of radiocarbon dates from cultural strata within the rockshelter to 17 . These three occupations are the Esperanza, Marcala, and Estanzuela phases. The Esperanza phase corresponds to the Early Archaic; the Marcala, to the Middle Archaic; and the Estanzuela, to the Formative and Early Classic periods. More precise temporal determinations will require more extensive radiocarbon dating. Dates presented in the following text are in uncalibrated radiocarbon years B.P. Calibrated dates when presented are two-sigma calibrated ages using INTCAL98 (Stuiver et al. 1998). More traditional B.C./A.D. calendar dates are also provided in the discussion of the Estanzuela occupation.

\section{Esperanza Occupation}

Strata IV-VI represent the earliest human occupation of El Gigante and correspond to the Early Archaic period. Stratum IV varies from 10 to $20 \mathrm{~cm}$ in thickness and is divided into two substrata (IVa and IVb). These strata are differentiated from those above and below by their light gray $(2.5 \mathrm{YR} 7 / 2$, 7.5YR 7/1) to gray (10YR 5/1) color, ashy texture, and a high density of bone fragments and lithics. Stratum V was divided into two substrata (Va and $\mathrm{Vb}$ ), which vary between 5 and $10 \mathrm{~cm}$ thick. The layer consisted of angular gravel, ash, and an abundance of coarse charcoal, organic material, flaked lithics, and large mammal bone. Substratum Va was dark gray (10YR 4/1), whereas the underlying substratum $\mathrm{Vb}$ was increasingly gravelly and pumicy, with a pinkish gray color (7.5YR 7/2). Stratum VI, as mentioned above, represents the prehuman floor of the rockshelter on which cultural material was deposited by its early inhabitants.

The cultural materials recovered in Strata IV-VI are the remains of human occupation from a largely undisturbed residential context. The lithic debris recovered include examples of well-fashioned wide-stemmed projectile points, both with and without basal notches or basal fluting (Figure 5). They correspond stylistically to the Pedernales point types identified in several sites in Mexico (Hole 1986; MacNeish et al. 1967:78; Ranere et al. 2009). These projectile points have been incorrectly linked to points in the "fishtail" tradition in lowerCentral America because of the flaring nature of their stemmed bases (MacNeish and NelkenTerner 1983). ${ }^{3}$ The Pedernales point type was originally identified in Texas, dates to 4000-3000 B.P. (Perttula 2009), and is much more recent than the El Gigante materials. Reyes González and Winter (2010) identify similar points in Oaxaca, Mexico, where stemmed points with basally notched "ears" are called Xaagá points and wide-stemmed "earless" examples are Jícara points. The same range of variation is found in the El Gigante collection as it is elsewhere in the Marcala region (Bullen and Plowden 1963).

Seven radiocarbon dates, five from the 2000-2001 excavations and two from Hasemann's earlier explorations, date this occupation to between 10,040 and 9100 B.P. Of the five dates from the 2000-2001 excavations, sample 11 was from Stratum IV (9650-9530 B.P.), and samples 12 and 13 were from Stratum V and dated to $9660-9540$ B.P. and 9270-9150 B.P. Two accelerator mass spectrometry (AMS) radiocarbon samples were taken from intrusive materials recovered from levels below Stratum V. These included a maguey quid (sample 14) from Stratum VI (9280-9200 B.P.) and a piece of cordage (sample 15) from Stratum VIII (9330-9250 B.P.). As mentioned above, the two dates run by Hasemann also come from the early occupation. Together these seven dates on charcoal and organic remains provide a secure basis for dating the initial occupation of the El Gigante rockshelter.

Early Holocene subsistence economies are often difficult to characterize because of the poor preservation of organic remains of this age. This was not the case at El Gigante. Evidence was found for the exploitation of a wide variety of plants and small animals including waterfowl and aquatic fauna. The presence of projectile points in the deposits indicates the importance of large mammal hunting. The most frequently recovered faunal remains were common deer. Nevertheless, teeth from two large Pleistocene bovids (Euceratherium sp.) also were recovered that could reflect the late and limited 

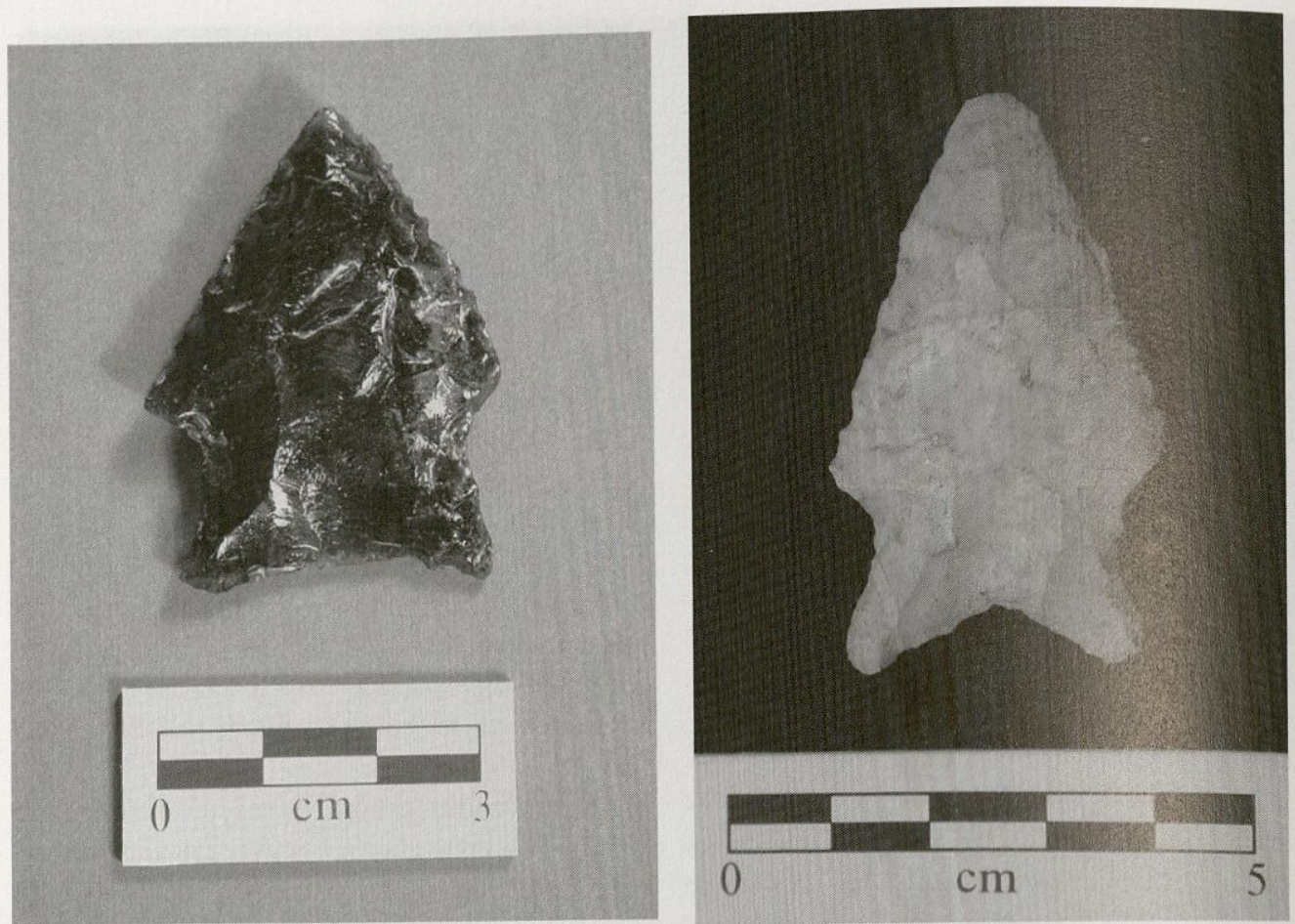

Figure 5. Late Paleoindian projectile points from EI Gigante. The obsidian point on the left shows basal fluting.

exploitation of the now extinct shrub-ox. However, these two teeth were recovered from what we believe are pre-occupation levels in Strata VI and VIIa, and because they exhibit no signs of butchering, burning, or other modification, it is possible that they predate the cultural occupation of the rockshelter.

Plant resources recovered include maguey (Agave sp.), represented by cut stems and quids, ciruela seeds from the hog plum fruit (Spondias sp.), and avocado seeds (Persea americana). These plant resources would have reached their wet-season peak during September. There is no indication that El Gigante was occupied year-round. Instead, based on seasonally available plant resources, the optimum window for occupation of this site may have been early July through September. It is likely that El Gigante was used sporadically throughout the Esperanza occupation by small hunting and gathering groups that timed their departure from the rockshelter against resource declines brought about by the onset of the dry season.

\section{Marcala Occupation}

The second occupation of the El Gigante rockshelter is represented by a series of levels that compose Stratum III and correspond to the Middle Archaic period. Stratum III varies from 15 to 30 $\mathrm{cm}$ in thickness and consists of bright yellow sediments that are interbedded with gravelly gray ash and very fine sediment eroded from the walls and roof of the cave. This stratum was subdivided into six substrata that varied in depth and were encountered as deep as $70 \mathrm{~cm}$ below surface.

The cultural materials recovered in Stratum III consist of large quantities of charcoal, organic material, flaked lithics, and a range of faunal remains. Three radiocarbon assays (samples 8-10) were analyzed from Stratum III and date the Marcala phase to the Middle Archaic period, from 7350 to 6050 B.P. These dates were all derived from substrata of Stratum III and include sample 8, which was taken directly from an in situ hearth/refuse feature.

Notably absent from Marcala phase deposits were bifacial projectile points, which are com- 


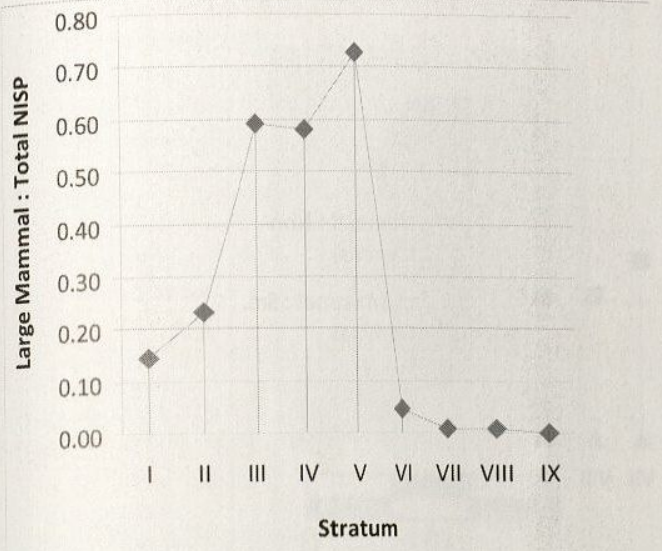

Figure 6. Relative proportion of large mammal taxa in the faunal assemblage.

monly associated with specialized large game hunting. The disappearance of flaked-stone projectile points after 10,000 B.P. has been observed elsewhere in Central America (Faught 2006; Ranere and Cooke 1996) and occurred as a result of either changes in foraging strategies away from large mammal hunting toward small animal exploitation or a shift to more perishable hunting equipment in the form of bone or hardwood projectile points.

A comparison of the faunal remains in the Esperanza and Marcala deposits supports the interpretation of broader hunting and foraging practices during these two phases. Ugan (2005:75) has suggested that declines in relative numbers of large and small game animals would imply a decline in foraging returns. To examine this relationship we compare the number of identified specimens (NISP) classified as large mammals with the total NISP of the faunal assemblage over time (Emery 2004:26). These results are displayed by stratum in Figure 6 . Two other Abundance Indexes were calculated to describe the changes in the relative frequency of large-animal remains in the archaeological assemblage ( $\mathrm{cf}$. Bayham 1979). These changes in the relative frequency of large fauna are presented in Figure 7. Large mammal NISPs were compared with the assemblages of small mammal and nonmammal taxa recovered.

Although deer does not disappear between the Esperanza and the Marcala phases, the faunal results show that after the rockshelter's initial occupation (represented by Stratum VI), there is a spike and then a consistent decline in both the absolute fre- quency of large-mammal bone in the assemblage and their relative frequency in relation to smaller mammals and other diverse taxa such as crabs, snails, birds, and turtles. We believe that these trends reflect a modification in subsistence practices and a decline in foraging returns since there is no significant change in the size of deer bone fragments that would affect this ratio as a result of modifications in food-processing strategies (Scheffler 2008:Figure 34). It remains unclear whether the increased utilization of a broader suite of animal resources was a result of climate change and a decline in deer populations, as Bayham (1979:233) suggests for North America, or a function of evolving and changing exploitation practices.

Occupation continued to be sporadic throughout the Marcala phase, when the rockshelter was used as a periodic collection station for wild foods. A range of plant species have been recovered from Marcala deposits, including ciruela (Spondias sp.), avocado (Persea sp.), custard apple (Annona sp.), and hackberry (Celtis sp.). The abundance of these fruiting plants, together with the continued exploitation of maguey (Agave sp.) and the possible use of wild grasses (Setaria sp.), suggests longer and/or more frequent occupations between late May and October.

Indications of longer or more frequent occupations of El Gigante come from two lines of evidence: an increase in the number of multiuse hearth and pit features and a rise in the frequency of charcoal within stratigraphic levels dating to this phase. The hearth and refuse pits are shallow grass-lined depressions that may have served first as small storage features and then as fire hearths. There are no deep storage pits at El Gigante like those described for Guilá Naquitz (Flannery 1986). Higher levels of wood charcoal were observed during the excavation of Marcala levels compared with earlier Esperanza levels. This was confirmed by laboratory analyses of the carbon content in a sedimentary column (Scheffler 2008). Together these data suggest that foragers were using the rockshelter as an extended base camp for longer periods of time in comparison with the previous Esperanza phase. This may indicate a gradual transition from generalized foraging to logistically based resource exploitation made possible by more intensive exploitation of faunal resources and both annual and perennial plants. 


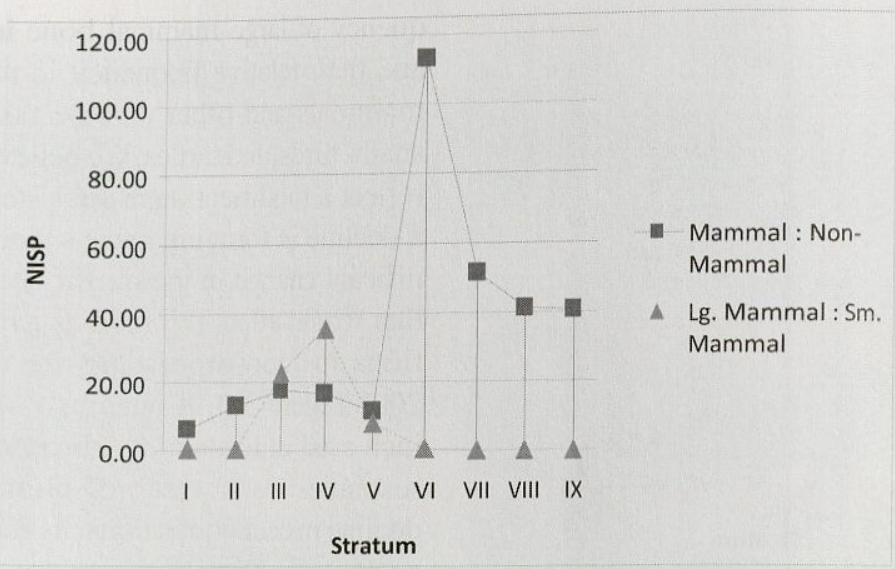

Figure 7. Faunal Abundance Index (AI) values, comparing mammal with nonmammal components (squares) and the proportion of large to small taxa (triangles).

\section{Estanzuela Occupation}

The third occupation is represented by materials recovered in Strata I and II. This occupation corresponds to the time period often referred to as the Early to Late Formative and Early Classic periods in Honduran prehistory (Clark and Gosser 1995; Healy 1974, 1992; Henderson and Beaudry-Corbett 1993; Joyce and Henderson 2001). The Early Formative period in Honduras is marked by the appearance of sedentary ceramic-producing groups (Joyce and Henderson 2001; Kennedy 1980, 1986), which by the Late Formative had formed complex ranked and chiefdom-level societies (Dixon et al. 1994; Healy 1992; Hirth 1988; Hirth et al. 1989). These groups practiced a mixed economy of food production, hunting, and foraging, which at El Gigante is reflected by the appearance of domesticated maize, beans, and squash in contexts where hunting and wild plant collection continues. Strata I and II consist of $60 \mathrm{~cm}$ of deposits ranging from a light (7.5YR 7/1) to very dark gray (10YR 3/1) color and encompassing 10 smaller lenses of distinct interbedded strata. Cultural disturbances including the effects of looting are most severe in these two strata.

Strata I and II are both rich in organic material as well as flaked- and ground-stone lithic remains. Stratum I consists of $30 \mathrm{~cm}$ of densely packed organic material including matted grass, wood, leaves, petates (woven mats), floral material, and bone, as well as sparse amounts of ceramics. Stra- tum II was more compact and had lower amounts of organic remains; it was composed mainly of interspersed fine ashes, charcoal, and limited bone fragments. Seven radiocarbon assays together with ceramic cross-dating situate the Estanzuela phase at 3900-1500 B.P. (1950 B.C.-A.D. 450). The Early Estanzuela occupation (samples 5-7) dates from 3840 to 2820 B.P., while the dated samples (1-4) from the Late Estanzuela phase span the years from 2320 to 1870 B.P. Two of these dates (samples 4 and 7) were recovered from Stratum III, indicating some mixing of later material into earlier layers.

The two most significant changes in the archaeological record at El Gigante during the Estanzuela occupation are the appearance of maize and the presence of ceramics. Maize and ceramics both appear to have arrived at El Gigante sometime in the mid- to late Estanzuela phase. It remains unclear if maize and ceramics were introduced into the region along the natural corridor leading into central Honduras and the Comayagua Valley (JoesinkMandeville 1993) or via the Lempa River from the coast of El Salvador (Goralski 2008).

The morphological structure of maize at El Gigante (Figure 8) indicates that it entered the region as a well-developed domesticate. ${ }^{4}$ Two of the radiocarbon assays (samples 3 and 4) are AMS dates taken from maize that establish its presence in the region at between 2320 and 1970 B.P. More AMS dates will be required to disentangle the chronological issues involving the introduction and 


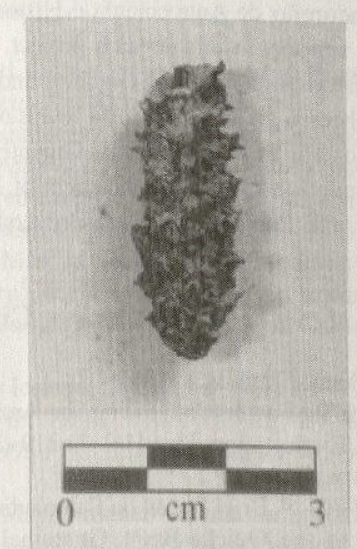

Cob 2-14b

$400-350 \mathrm{BC}$ and $310-210 \mathrm{BC}$ (2-sigma calibrated AMS date)

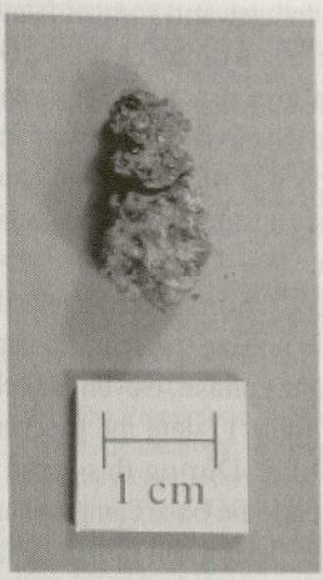

Cob 18-20

$100 \mathrm{BC}$ - AD 70

(2-sigma calibrated AMS date)

Figure 8. Dated maize cobs at El Gigante.

adoption of maize at El Gigante and throughout the southern highlands of Honduras.

The duration of occupation at El Gigante during the Estanzuela period remains unclear. The lack of visible storage features and the absence of architectural modifications often associated with permanent occupation in caves (Scheffler 2008) suggest that El Gigante was not occupied yearround. ${ }^{5}$ To date, only limited surface reconnaissance has been conducted along the Estanzuela River. Nevertheless, two open-air prehispanic sites were identified at El Pelón and Los Gentiles (Figure 1). Formative and Classic period sherds were identified at El Pelón, suggesting that El Gigante may have been a periodic foraging camp and storage area used by residents from other local hamlet communities.

We suspect that over the course of the Estanzuela phase, El Gigante was used for a range of harvesting and foraging activities throughout the annual cycle. This is evident in an increase in the breadth of resources represented in the rockshelter and the increase in the number of seasons that their exploitation spanned. Domesticates such as maize, beans, and squash were added to hunting and foraging, along with an expanded use of both fruit trees (e.g., avocado, ciruela) and the seasonal collection of wild resources such as maguey. Flannery (1986) outlines a similar shift in cave uti- lization in both the Valley of Oaxaca and the Tehuacán Valley, Mexico. In both instances, seasonal collecting remained an important component of the subsistence economy long after the establishment of agricultural subsistence systems. Flannery suggests that caves and rockshelters continued to be used as temporary base camps by foragers and farmers alike. During the Early Estanzuela phase the dispersal of agricultural fields around the rockshelter could have allowed El Gigante to be used as a semipermanent residential base or storehouse for several extended families before the appearance of permanent open-air community settlements. The recovery of Classic and later-period ceramics from other caves and rockshelters in the region indicates that they continued in use as periodic collection and foraging stations well past the Formative period (Scheffler 2008).

\section{Conclusion}

A renewed interest in the early and middle Holocene has begun to provide important evidence on early human adaptations in Central America. Valuable new information has been collected on Holocene adaptations in Mexico, Guatemala, Belize, and Panama. The research at El Gigante provides new data on human adaptation recovered from a rockshelter with well-preserved cultural 
deposits occupied by forager and forager-farming groups throughout the length of the Holocene. Outstanding preservation in a dry rockshelter environment has permitted the recovery of a wide array of information on the use of floral and faunal resources in a previously unstudied highland region of southern Honduras.

Three important occupations were identified at El Gigante. The first is an Early Archaic occupation during the Esperanza phase. Seven radiocarbon assays (11-17 in Table 1) date the Esperanza phase to $10,040-9100$ B.P. During this period El Gigante was used as a periodic base camp for hunting and foraging groups during the months of late May into October. The presence of bifacially worked projectile points in both obsidian and chert indicates the importance of large mammal hunting, with a specific focus on deer.

The second occupation corresponds to the Middle Archaic period referred to as the Marcala phase. Three radiocarbon assays ( $8-10$ in Table 1 ) date this occupation to $7350-6050$ B.P. Specialized projectile point inventories disappear from the assemblage, and while large mammal hunting continued, there was an increase in the exploitation of a broad spectrum of small animals. This may be a response to regional climatic change and a shrinking of pineoak zones throughout the Holocene (Hodell et al. 2000), which exerted pressure on local foragers to intensify exploitation within their highland habitat. Nevertheless, an increase in multiuse hearth and refuse pits suggests that groups were using El Gigante as an extended base camp during the regularly scheduled collection of wild foods in the area.

The third occupation is the Estanzuela phase, which corresponds to the Early-Late Formative and the Early Classic periods elsewhere in Honduras. At El Gigante the Estanzuela phase is dated to $3900-1500$ B.P. (1950 B.C.-A.D. 450) on the basis of ceramic cross-dating and seven radiocarbon dates recovered from stratigraphic contexts (samples 1-7 in Table 1). Two important chronological markers appear during this period: the incorporation of maize, beans, and squash agriculture into the subsistence diets of El Gigante residents and the appearance of pottery for food preparation and storage. How El Gigante's role changed in relation to the appearance of open-air sedentary communities along the valley bottom of the Estanzuela River is a topic that requires more systematic study.
Acknowledgments. We would like to thank the Instituto Hondureño de Antropología e Historia for its contributions and support in this research project. Dr. George Hasemann initiated research at El Gigante, and his premature demise has been a great setback to all levels of research in Honduras. Funds for excavations at El Gigante were provided by the Foundation for the Advancement of Mesoamerican Studies, Inc., and Pennsylvania State University.

\section{References Cited}

Bayham, Frank E.

1979 Factors Influencing the Archaic Pattern of Animal Exploitation. Kiva 44(2-3):219-235.

Brown, Kenneth

1980 A Brief Report on Paleoindian-Archaic Occupation in the Quiche Basin, Guatemala. American Antiquity 45(2):313-324.

Bullen, Ripley P., and William W. Plowden

1963 Preceramic Archaic Sites in the Highlands of Honduras. American Antiquity 28(3):382-385.

Clark, John, and David Cheetham

2002 Mesoamerica's Tribal Foundations. In The Archaeology of Tribal Societies, edited by William Parkinson, pp. 278-339. International Monographs in Prehistory 15. Archaeological Series, Ann Arbor.

Clark, John, and Dennis Gosser

1995 Reinventing Mesoamerica's First Pottery. In The Emergence of Pottery. Technology and Innovation in Ancient Societies, edited by William Barnett and John Hoopes, pp. 209-221. Smithsonian Institution Press, Washington, D.C.

Coe, Michael

1960 A Fluted Point from Highland Guatemala. American Antiquity 25(4):412-413.

Cooke, Richard

2005 Prehistory of Native Americans on the Central American Land Bridge: Colonization, Dispersal, and Divergence. Journal of Archaeological Research 13:129-187.

Dixon, Boyd, Leroy Joesink-Mandeville, Nobukatsu Hasebe, Michael Mucio, William Vincent, David James, and Kenneth Petersen

1994 Formative Period Architecture at the Site of Yarumela, Central Honduras. Latin American Antiquity 5(1):70-87.

Emery, Kitty

2004 Maya Zooarchaeology: New Directions in Method and Theory. Cotsen Institute of Archaeology, Monograph 51. University of California, Los Angeles.

Faught, Michael

2006 Paleoindian Archaeology in Florida and Panama: Two Circumgulf Regions Exhibiting Waisted Laneolate Projectile Points. In Paleoindian Archaeology: A Hemispherical Perspective, edited by Juliet Morrow and Cristóbal Gnecco, pp. 164-183. University of Florida Press, Gainesville.

Flannery, Kent (editor)

1986 Guilá Naquitz: Archaic Foraging and Early Agriculture in Oaxaca, Mexico. Academic Press, Orlando.

Goralski, Craig

2008 An Examination of the Uapala Ceramic Sphere Using Instrumental Neutron Activation Analysis. Unpublished Ph.D. dissertation, Department of Anthropology, Pennsylvania State University, University Park.

Gruhn, Ruth, Alan Bryan, and Jack Nance

1977 Los Tapiales: A Paleo-Indian Campsite in the 
Guatemalan Highlands. Proceedings of the American Philosophical Society 121:235-273.

Healy, Paul

1974 The Cuyamel Caves: Preclassic Sites in Northeast Honduras. American Antiquity 39(3):435-447.

1992 Ancient Honduras: Power, Wealth, and Rank in Early Chiefdoms. In Wealth and Hierarchy in the Intermediate Area, edited by Fred Lange, pp. 85-108. Dumbarton Oaks Library and Research Collection, Washington, D.C.

Henderson, John, and Marilyn Beaudry-Corbett (editors) 1993 Pottery of Prehistoric Honduras. Cotsen Institute of Archaeology, Monograph 35. University of California, Los Angeles.

Hester, Thomas, Harry Iceland, Dale Hudler, and Harry Shafer 1996 The Colha Preceramic Project: Preliminary Results from the 1993-1995 Field Seasons. Mexicon 18:45-50.

Hirth, Kenneth

1988 Beyond the Maya Frontier: Cultural Interaction and Syncretism Along the Central Honduran Corridor. In The Southeastern Maya Periphery, edited by Elizabeth Boone and Gordon Willey, pp. 297-334.Dumbarton Oaks, Washington, D.C.

Hirth, Kenneth, Nedenia Kennedy, and Maynard Cliff

1989 Chronology and Ceramic Variability Within the El Cajon Region. In Archaeological Research in the El Cajon Region, Vol. 1: Prehistoric Cultural Ecology, edited by Kenneth Hirth, Gloria Lara, and George Hasemann, pp. 207-232. Instituto Hondureño de Antropología e Historia, Tegucigalpa; and University of Pittsburgh, Pittsburgh.

Hodell, David A., Mark Brenner, and Jason Curtis

2000 Climate Change in the Northern American Tropics and Subtropics Since the Last Ice Age: Implications for Environment and Culture. In Imperfect Balance: Landscape Transformations in the Precolumbian Americas, edited by David Lentz, pp. 13-38. Columbia University Press, New York

Hole, Frank

1986 Chipped Stone Tools. In Guilá Naquitz: Archaic Foraging and Early Agriculture in Oaxaca, Mexico, edited by Kent Flannery, pp. 97-139. Academic Press, Orlando.

Iceland, Harry

1997 The Preceramic Origins of the Maya: The Results of the Colha Preceramic Project in Northern Belize. Unpublished Ph.D. dissertation, Department of Anthropology, University of Texas, Austin.

Joesink-Mandeville, Leroy

1993 Comayagua Valley. In Pottery of Prehistoric Honduras, edited by John Henderson and Marilyn BeaudryCorbett, pp. 234-247. Cotsen Institute of Archaeology, Monograph 35 . University of California, Los Angeles.

Jones, John

1994. Pollen Evidence for Early Settlement and Agriculture in Northern Belize. Palynology 18:205-211.

Joyce, Rosemary, and John Henderson

2001 Beginnings of Village Life in Eastern Mesoamerica. Latin American Antiquity 12(1):5-24.

Kennedy, Nedenia

1980 The Formative Period Ceramic Sequence from Playa de los Muertos, Honduras. Unpublished Ph.D. dissertation, Department of Anthropology, University of Illinois, Urbana-Champaign.

1986 The Periphery Problem and Playa de los Muertos: A Test Case. In The Southeast Maya Periphery, edited by Patricia Urban and Edward Schortman,pp. 179-193. University of Texas Press, Austin.

Lohse, Jon

2007 In Search of the Preceramic: 2006 Season Investiga- tions at Actun Halal, Belize. Electronic document, http://www.famsi.org/reports/06019/06019Lohse01.pdf, accessed May 16, 2012.

Lohse, Jon, Jaime Awe, Cameron Griffith, Robert M. Rosenswig, and Fred Valdez, Jr.

2006 Preceramic Occupations in Belize: Updating the Paleoindian and Archaic Record. Latin American Antiquity 17(2):209-226.

Long, Austin, and Gail J. Fritz

2001 Validity of AMS Dates on Maize from the Tehuacán Valley: A Comment on MacNeish and Eubanks. Latin American Antiquity 12(1):87-90.

MacNeish, Richard S.

1986 The Preceramic of Middle America. Advances in World Archaeology. In Advances in World Archaeology, edited by Fred Wendorf and Angela Close, pp. 93-129. Academic Press, Orlando.

MacNeish, Richard S., and Antoinette Nelken-Terner 1983 Preceramic of Mesoamerica. Journal of Field Archaeology 10:71-84.

MacNeish, Richard S., Antoinette Nelken-Terner, and Irmgard W. Johnson

1967 The Prehistory of the Tehuacán Valley, Vol. 2: The Non-Ceramic Artifacts, edited by Douglas S. Byers. University of Texas Press, Austin.

Morrow, Juliet, and Toby Morrow

1999 Geographic Variation in Fluted Projectile Points: A Hemispheric Perspective. American Antiquity 64:215-231.

Pearson, Georges

2002 Pan-Continental Paleoindian Expansions and Interactions as Viewed from the Earliest Lithic Industries of Lower Central America. Unpublished Ph.D. dissertation, Department of Anthropology, University of Kansas, Lawrence.

2003 First Report of a New Paleoindian Quarry Site on the Isthmus of Panama. Latin American Antiquity 14:311-322.

Pearson, Georges, and Richard Cooke

2003 The Role of the Panamanian Land Bridge During the Initial Colonization of the Americas. Antiquity 76:931-932.

Perttula, Timothy

2009 Typological Labeling of Early Holocene Projectile Points. Proceedings of the National Academy of Science 106:1073.

Piperno, Dolores, and Kent Flannery

2001 The Earliest Archaeological Maize (Zea mays L.) from Highland Mexico: New Accelerator Mass Spectrometry Dates and Their Implications. Proceedings of the National Academy of Science 98:2101-2103.

Piperno, Dolores, and Deborah Pearsall

1998 The Origins of Agriculture in the Lowland Neotropics. Academic Press, San Diego.

Piperno, Dolores, Anthony Ranere, Irene Holst, José Iriarte, and Ruth Dickau

2009 Starch Grain and Phytolith Evidence from Early Ninth Millennium B.P. Maize from the Central Balsas River Valley, Mexico. Proceedings of the National Academy of Science 106:5019-5024.

Pohl, Mary D., Kevin O. Pope, John G. Jones, John S. Jacob, Dolores R. Piperno, Susan D. de France, David L. Lentz, John A. Gifford, Marie E. Danforth, and J. Kathryn Josserand

1996 Early Agriculture in the Maya Lowlands. Latin Amer ican Antiquity 7:355-372.

Ranere, Anthony

2006 The Clovis Colonization of Central America. In Paleoindian Archaeology: A Hemispherical Perspective, edited 
by Juliet Morrow and Cristóbal Gnecco, pp. 69-85. University of Florida Press, Gainesville.

Ranere, Anthony, and Richard Cooke

1996 Stone Tools and Cultural Boundaries in Prehistoric Panama, an Initial Assessment. In Paths to Central American Prehistory, edited by Fred Lange, pp. 49-77. University Press of Colorado, Niwot.

Ranere, Anthony, Dolores Piperno, Irene Holst, Ruth Dickau, and José Iriarte

2009 The Cultural and Chronological Context of Early Holocene Maize and Squash Domestication in the Central Balsas River Valley, Mexico. Proceedings of the National Academy of Science 106:5014-5018.

Reyes González, Liliana Carla, and Marcus Winter

2010 The Early Formative Period in the Southern Isthmus:

Excavations at Barrio Tepalcate, Ixtepec, Oaxaca. Ancient Mesoamerica 21:151-163.

Rue, David

1989 Archaic Middle American Agriculture and Settlement: Recent Pollen Data from Honduras. Journal of Field Archaeology 16:177-184.

Scheffler, Timothy

2008 The El Gigante Rock Shelter, Honduras. Unpublished Ph.D. dissertation, Department of Anthropology, Pennsylvania State University, University Park.

Snarskis, Michael

1979 Turrialba: A Paleo-Indian Quarry and Workshop Site in Eastern Costa Rica. American Antiquity 44(1):125-138.

Sorensen, Jerrel, and Kenneth Hirth

1985 Minas precolombinas y talleres de obsidiana en La Esperanza, Dept. Intibuca. Yaxkin 7:31-45.

Stuiver, Minze, Paula Reimer, Edouard Bard, J. Warren Beck, G. S. Burr, Konrad Hughen, Bernd Kromer, Gerry McCormac, Johannes Van Del Plicht, and Marco Spurk

1998 INTCAL98 Radiocarbon Age Calibration, 24,000-0 calBP. Radiocarbon 40(3): 1041-1083.

Ugan, Andrew

2005 Does Size Matter? Body Size, Mass Collecting, and Their Implications for Understanding Prehistoric Foraging Behavior. American Antiquity 70(1):75-89.

Voorhies, Barbara

1976 The Chantuto People: An Archaic Period Society of the Chiapas Littoral, Mexico. Papers of the New World Archaeological Foundation No. 41. Brigham Young University, Provo.
2004 Coastal Collectors in the Holocene: The Chantuto People of Southwest Mexico. University of Florida Press, Gainesville.

Voorhies, Barbara, Douglas J. Kennett, John G. Jones, and Thomas A. Wake

2002 A Middle Archaic Archaeological Site on the West Coast of Mexico. Latin American Antiquity 13:179-200.

Webster, David, David Rue, and Alfred Traverse

2005 Early Zea Cultivation in Honduras: Implications for the Iltis Hypothesis. Economic Botany 59(2):101-111.

\section{Notes}

1. These two radiocarbon dates were run at the Illinois State Geological Survey (ISGS \#2965-2, 2966-3).

2. George Hasemann's untimely death in 1998 was a tremendous setback for both Honduran archaeology and research at El Gigante. His death led to the loss of excavation momentum at El Gigante, with the results of the 1993 and 1994 field investigations never coming to light.

3. For a recent discussion of fishtail and Clovis projectile points, see Morrow and Morrow 1999.

4. The morphology of the El Gigante maize along with the recovery of the majority of the cobs from Strata I and II suggested a late adoption of maize into this region. To assess the rate of morphological change in maize, measurements were made on one dimension of maize productivity, cob diameter, to assess possible directional selection in the maize population. These measurements found no statistically distinguishable change in cob size within or between strata within the El Gigante rockshelter (Scheffler 2008).

5 . The absence of storage facilities by itself does not preclude more lengthy occupations. The dry nature of the cave combined with the loose strata of the rockshelter floor may have made above-ground storage more practical than storage in subsurface pits.

Submitted: September 21, 2011; Revised: May 21,2012; Accepted: June 28, 2012. 